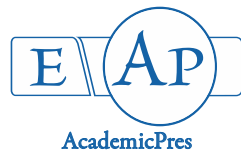

\title{
The Clinicopathological Evaluations of the Efficacy of Incorporation of Amantadine Hydrochloride in the Treatment of West African Dwarf Goats Experimentally Infected with Peste des Petits Ruminants Virus
}

\author{
Iniobong C.I. UGOCHUKWU ${ }^{1}$, Sunday I. IDOKO², Jacinta N. OMEKE ${ }^{1 *}$, \\ Chioma I. ANEKE ${ }^{1}$, Nuhu A. SANI ${ }^{2}$, Nnenna T. EMEJUO ${ }^{1}$, \\ Chioma F. IKEM ${ }^{3}$, Emmanuel I. UGOCHUKWU ${ }^{3}$ \\ ${ }^{1}$ University of Nigeria, Department of Veterinary Pathology and Microbiology, Nsukka, Nigeria; iniobong.ugochukwu@unn.edu.ng; \\ jacinta.omeke@unn.edu.ng ("correspondingauthor); chioma.aneke@unn.edu.ng; tochi.emejuo@unn.edu.ng; \\ ${ }^{2}$ University of Abuja, Department of VeterinaryPathology, Abuja, Nigeria; idoko.sunday@uniabuja.edu.ng; saninuhuabdul@yahoo.com; \\ ${ }^{3}$ University of Nigeria, Department of Veterinary Medicine, Nsukka, \\ Nigeria; chioma.ikem.174285@unn.edu.ng; emmanuel.ugochukwu@unn.edu.ng
}

\begin{abstract}
Peste des petits ruminants poses a major threat to the development of small ruminant production. The objective of this study was to determine the comparative efficacy of amantadine hydrochloride ( $\mathrm{HCl})$, oxytetracycline long acting (LA) and levamisole in West African dwarf (WAD) goats experimentally infected with PPR. In addition to the presence of the characteristic clinical signs, complement ELISA and haem agglutination inhibition (HI) tests were used to confirm PPR infection in the West African dwarf goats, then treatment was instituted in the different groups namely, group 1 which was treated with amantadine $\mathrm{HCl}$ orally, oxytetracycline LA intramuscularly (IM) and levamisole per os. Group 2 was treated with oxytetracycline LA IM and levamisole. Group 3 was treated with levamisole while group 4 served as untreated control. The physiological parameters namely rectal temperature, pulse rate and respiratory rates of the different groups were recorded. The mortality rates in the different treatment groups were also recorded. The respiratory rates of the WAD goats increased as the infection progressed, but the increase was not significant $(P>0.05)$. The treatment helped reduce the respiratory rates in the treated WAD. The rectal temperatures of all the animals in the different treatment groups increased only slightly as the infection progressed and was not significant $(P>0.05)$. The percentage mortalities were $0 \%$ in Group 1, 25\% in the Group 2, $50 \%$ in the treated group 3 and highest $(75 \%)$ in the untreated group respectively. In conclusion, incorporation of specific antiviral agents like amantadine hydrochloride in the treatment regimen with oxytetracycline and levamisole particularly during the early stages of the infection can reduce morbidity and mortality of the disease to the barest minimum.
\end{abstract}

Keywords: amantadine $\mathrm{HCl}$; levamisole; mortality; oxytetracycline; peste des petits ruminants

\section{Introduction}

There are limitations of the contribution of small ruminants to household economies and livelihood in $3^{\text {rd }}$ world countries due to factors such as infectious diseases, such as peste des petits ruminants (PPR), poor nutrition and marketing systems (Mbyuzi et al., 2014). This disease
PPR is a disease of economic and veterinary importance leading to considerable economic losses (Ugochukwu et al., 2019).

PPR is an increasingly alarming contagious, viral disease (Balamurugan et al., 2014; Khaskheli et al., 2017). It is also a transboundary disease causing important economic losses due high morbidity and mortality, and has therefore been classified among diseases that must be reported to the World Organisation for Animal Health (OIE) (Abubakar

Received: 01 Jul 2019. Received in revised form: 10 Dec 2019. Accepted: 19 Dec 2019. Published online: 24 Dec 2019. 
380

et al., 2011; Odombi et al., 2011; Libeau et al., 2014). It poses a major threat to the development of small ruminant production in all areas where it has been reported, namely Africa, the Middle East and Asia (Diallo, 2006; Chauhan et al., 2009; Baron et al., 2011; Odombi et al., 2011).

PPR mortality rates in affected small ruminant populations may reach $100 \%$ whereas rates may be $20 \%$ or less in endemic areas (Abu Elzein et al., 1990; Roeder and Obi, 1999). Clinically, PPR is characterized by pyrexia, ulcerative stomatitis; catarrhal inflammation of the ocular and nasal mucosae, bronchopneumonia, and diarrhoea and in many cases could lead to death (Brown et al., 1991; Odombi et al., 2011; Balamurugan et al., 2014; Ugochukwu et al., 2019).

As poor people in developing countries rely on small ruminants, particularly goats, for their livelihoods, it has been suggested that the control of PPR in endemic regions should be reflected in developing poverty alleviation policies (Perry et al., 2002).

There is no specific treatment for peste des petits ruminants; however, drugs that control bacterial and parasitic complications may decrease mortality (Ugochukwu, 1983). Specifically, oxytetracycline and chlortetracycline are recommended to prevent secondary pulmonary infections (Islam et al., 2012). Anene et al. (1987) working on the treatment of goats with natural clinical infection with PPR found that despite using three different therapeutic regimens, the response of WAD goats to these treatment formulations was poor. This was attributed in part to failure to institute anti-diarrhoeic drugs (Anene et al., 1987) as recommended and shown by Wosu (1989) and Abubakar and Irfan (2014). However, Adu and Joannis (1985) reported that the use of PPR hyper immune serum in the treatment of animals in the early stages of the infection before the onset of diarrhoea resulted in the protection and recovery of the affected goats. Nevertheless, once diarrhoea has set in, treating with hyper immune serum becomes useless (Taylor, 1979). Levamisole apart from its anthelminthic activity, has been demonstrated to stimulate host defensive mechanism against some infections (Hardman and Limbird, 2001; Undiandeye et al., 2014). It is said to also promote vaccine-therapy particularly in low producing animals. Its immune-potentiating ability is said to be apparently due to its ability to stimulate cell mediated immunity and macrophage function by stimulating $T$ and $B$ cells proliferation and antibodies production (Chukwu, 1987; Hardman and Limbird, 2001). Levamisole is recognized as an immune-potentiator (Taki and Schwartz, 1994).

Since the time of Edward Jenner and Louis Pasteur, vaccines have contributed to prevention, control and even eradication of human and animal diseases more than any other tool available to human or veterinary medicine (Riedel, 2005; Lombard et al., 2007). Classical vaccine technologies, including inactivated and attenuated vaccines, have been used for decades with significant success against a number of viral and bacterial diseases of livestock (FAO, 2011; Meeusen et al., 2007). The use of vaccines in the effective control of PPR has been demonstrated (Ademosun, 1994). However, despite of the strict vaccination programs and other preventive and clinical measures the PPR outbreaks are frequent (Abubakar et al., 2015a), hence, the need to conduct this study, to determine the comparative efficacy of amantadine hydrochloride, oxytetracycline long acting and levamisole in West African dwarf (WAD) goats suffering from experimental infection with PPR

\section{Materials and Methods}

\section{Study area}

Nsukka, a town in Nsukka Local Government Area of Enugu State, Nigeria was our study area. Nsukka is situated at latitude $6^{\circ} 51^{\prime} 24^{\circ} \mathrm{N}$ and longitude $7^{\circ} 23^{\prime} 45^{\circ} \mathrm{E}$. The climate here is tropical. The average temperature in Nsukka is 24.9 ${ }^{\circ} \mathrm{C}$. The average annual rainfall is $1579 \mathrm{~mm}$ (Ugochukwu et al., 2017b).

\section{Experimental animals}

Sixteen WAD goats identified by neck tags consisting of eight males and eight females, whose ages ranged from 6 months to one year and weighing between $4 \mathrm{~kg}$ and $6 \mathrm{~kg}$ were purchased from Ibagwa-Aka Livestock Market, Igbo Eze South Local Government Area Enugu State, Nigeria and which by clinical and serological examination were confirmed to be negative for natural infection of PPR. They were allowed to stabilize for 7 days in the animal section of the Department of Veterinary Medicine, University of Nigeria, Nsukka. During the period of stabilization, the goats in the treated groups were administered with levamisole at the dose of $10 \mathrm{mg} / \mathrm{kg}$ given as a drench stat and oxytetracycline LA $20 \mathrm{mg} / \mathrm{kg}$ of body weight intramuscularly as cover against helminth and bacterial infections respectively.

\section{Experimental infection}

The WAD goats after a period of stabilization and acclimatization were experimentally infected by the application of mucopurulent nasal and ocular discharges using cotton wool swabs from goats adjudged and confirmed by haem agglutination inhibition test and complement-ELISA to be suffering from PPR infection; this was done according to standard procedures as described by Nduaka and Ihemelandu (1973). Three to five days after experimental infection, the goats were kept in a common pen and began to show classical clinical signs of PPR.

\section{Serological diagnosis}

Confirmation of PPR serologically in this study was mainly by c-ELISA in which about $5 \mathrm{ml}$ of blood was collected from the jugular vein of each animal and emptied into a sterile universal bottle, then placed in a slanting position for the blood to clot at room temperature for 1 hour. The expressed serum was centrifuged at $3000 \mathrm{rpm}$ for 15 minutes at $4{ }^{\circ} \mathrm{C}$ and a clear straw coloured serum was collected. PPR c-ELISA kit designed to detect antibodies directed against the nucleoprotein of peste des petits ruminants (PPR) virus, developed by $\mathrm{FAO}$ reference laboratory (CIRAD-EMVT, Montpellier, France) was used. Procedure for monoclonal antibody based competitive-ELISA was done according to Singh et al. (2004) and haem agglutination inhibition test done 
following the standard procedures as described by Ezeibe $e t$ al. (2003) and Manoharan et al. (2005).

\section{Study design}

After experimental PPR infection in these goats, PPR was confirmed by monoclonal antibody based competitiveELISA (c-ELISA) and haem agglutination inhibition (HI) tests. The 16 experimentally infected WAD goats were divided into three different chemotherapeutic groups as follows, goats in group 1, consisted of 4 WAD goats suffering from experimental infection of PPR and were treated with amantadine $\mathrm{HCl} 100 \mathrm{mg}$ bid $5 / 7$ per os by drenching, oxytetracycline LA $20 \mathrm{mg} / \mathrm{kg}$ of body weight Intramuscularly (IM) and levamisole $10 \mathrm{mg} / \mathrm{kg}$ body weight given as a drench. Group 2 consisted of 4 WAD goats suffering from experimental infection of PPR and were treated with oxytetracycline LA $20 \mathrm{mg} / \mathrm{kg}$ of body weight Intramuscularly (IM) and levamisole $10 \mathrm{mg} / \mathrm{kg}$ body weight given as a drench stat. Group 3 consisted of 4 WAD goats suffering from experimental infection of PPR and were treated with levamisole $10 \mathrm{mg} / \mathrm{kg}$ body weight given as a drench while group 4 consisted of $4 \mathrm{WAD}$ goats suffering from experimental infection of PPR which served as untreated control. The physiological parameters namely rectal temperature, pulse rate and respiratory rates of the different groups were recorded. The mortality rates in the different treatment groups were also recorded.

\section{Treatment}

Amantadine hydrochloride produced by Auden Mckenzie (Pharma Division) Ltd UK, administered at the dose of $100 \mathrm{mg} / \mathrm{kg}$ orally. Oxtetracycline hydrochloride long acting (Pfizer Inc. US (Primamycin/LA) was administered at the dose of $20 \mathrm{mg}$ of the drug per $\mathrm{kg}$ of body weight intramuscularly. Levamisole produced by Kahira Pharmaceuticals and Chemical industries Cairo, Egypt and administered at the dose of $10 \mathrm{mg} / \mathrm{kg}$ body weight per os.

Tissue sample collection, preservation and processing

Samples of the lung and intestines were collected from the experimental animals at post mortem. These samples were fixed in 10\% neutral buffered formaldehyde for histopathology tissue processing. These samples were all processed following standard procedures as described by Drury and Wallington (1980).

\section{Statistical analysis}

Mean values and standard deviation were calculated from the physiological parameters. Data and the results were compared statistically using students' T-test assessing the mutual statistical differences and analysed using Analysis of variance (ANOVA). Significance was accepted at $P \leq 0.05$.

\section{Results}

Clinical signs appeared 5 days post infection affecting respiratory and gastrointestinal systems and the following were observed clinically ante mortem, pyrexia, anorexia, cachexia, starry hair coat, respiratory distress evidenced by coughing, sneezing and mucous to muco-purulent nasoocular discharges as shown in Fig. 1 and diarrhoea (Fig. 2).
Post-mortem findings of the WAD goats that died post infection revealed starry hair coats, ulcerative cheilitis and ulcerative stomatitis as seen in Fig. 3. Predominantly seen were linear discontinuous haemorrhage (zebra stripes) on the mucosa of colon and rectum as shown in Fig. 4, frothy exudates in the respiratory pathways and pneumocongestion, this is shown in Fig. 5. The Histopathological findings include thickening of inter lobular spaces, pneumocongestion in interlobular spaces, infiltration of mononuclear cells into inter-alveolar and interlobular spaces in the lungs (Fig. 6). Fig. 7 shows ulceration of mucosal surface, focal areas of ulceration on the intestinal villi, haemorrhage on the lamina propria of the intestines. The result of the findings in these experiments involving the incorporation of Amantadine hydrochloride in the treatment regimen of PPR is presented in Tables 1 and 2.

The respiratory rates of the WAD goats as shown in Table 1 increased as the infection progressed, but the increase was not significant $(P>0.05)$. However, it would appear that the treatment helped reduce the respiratory rates in the treated WAD to a physiological normal level. The rectal temperatures of all the animals in the different treatment groups increased only slightly as the infection progressed and was not significant $(P>0.05)$. These are shown in Table 1.

The total percentage survival was $68.75 \%$ of all the animals in the 4 groups after day 27 of the experiment. The total percentage mortality in all the treatment groups was $31.25 \%$ indicating a reduced mortality pattern (Table 2 ). It is interesting to note that the percentage mortalities were $0 \%$ in group 1 and $25 \%$ in the group 2, 50\% in the group 3 and highest (75\%) in the untreated group. Goats in group 1 as shown in Fig. 8 showed recovery from some of the typical clinical manifestations of peste des petits ruminants.

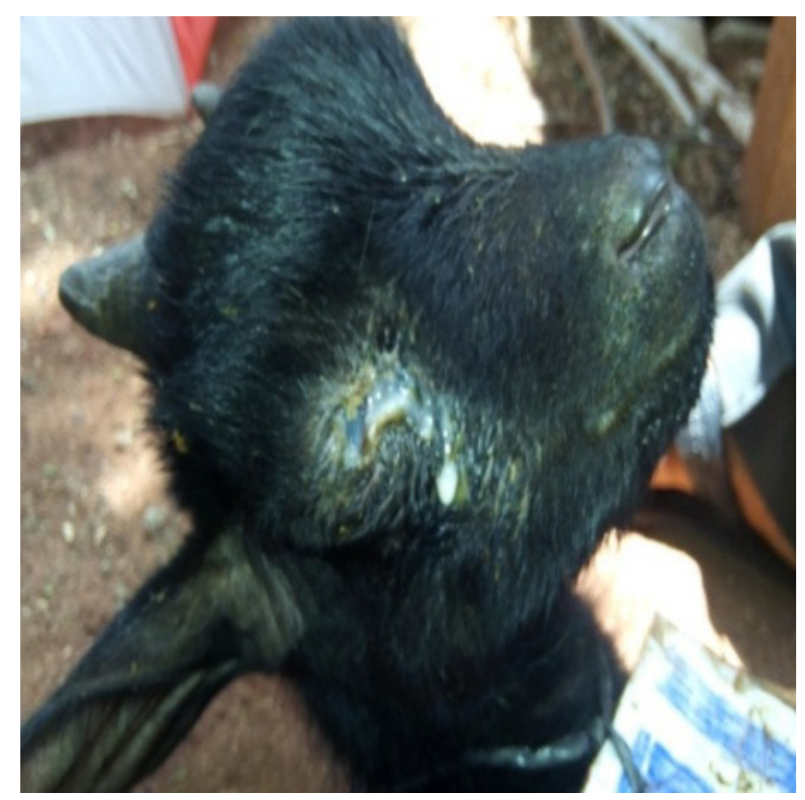

Fig. 1. A WAD goat suffering from PPR showing mucopurulent ocular discharges 
382

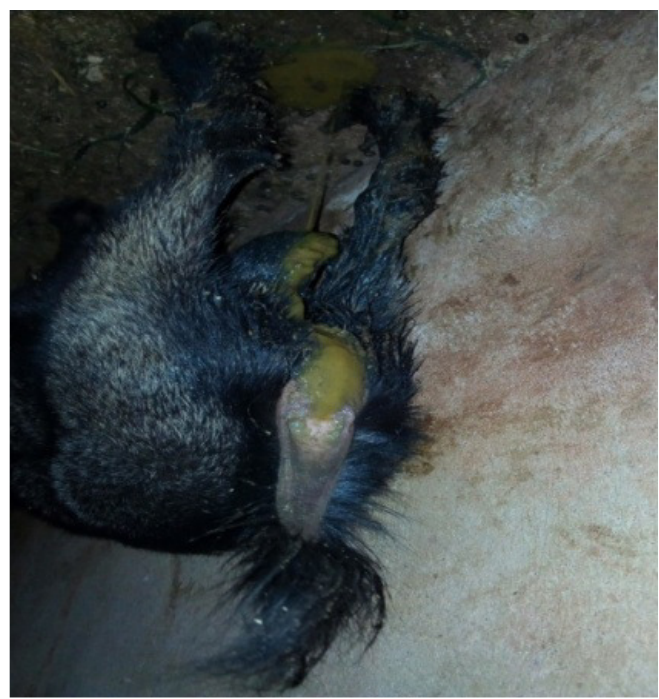

Fig. 2 Perineal region of a WAD goat suffering from PPR showing profuse watery diarrhoea

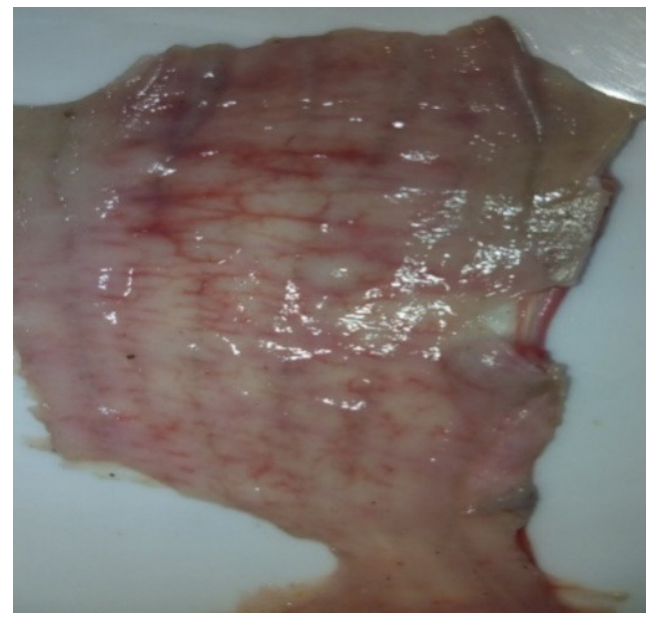

Fig. 4. Intestinal section showing linear discontinuous areas of haemorrhage (Zebra stripes)

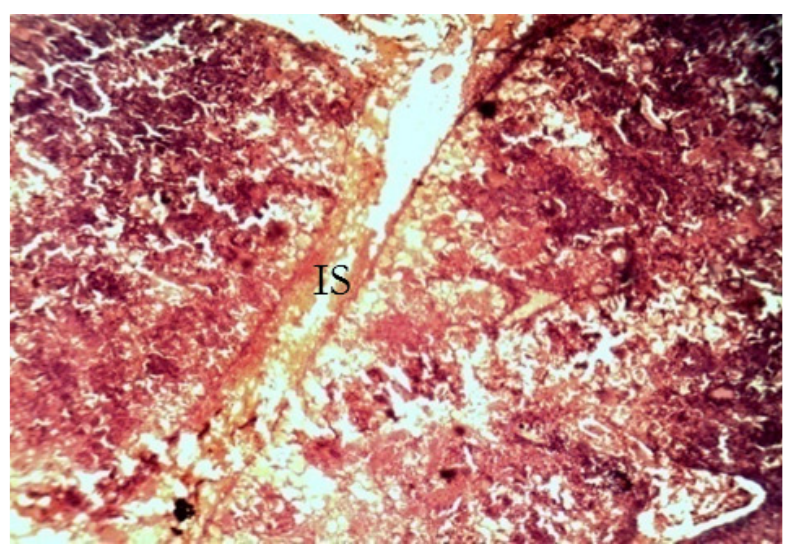

Fig. 6. Thickening of inter lobular spaces (IS) of the lungs, arrow pointing at pulmonary congestion in interlobular spaces, infiltration of mononuclear cells into inter-alveolar and interlobular spaces X $100 \mathrm{H} \& \mathrm{E}$

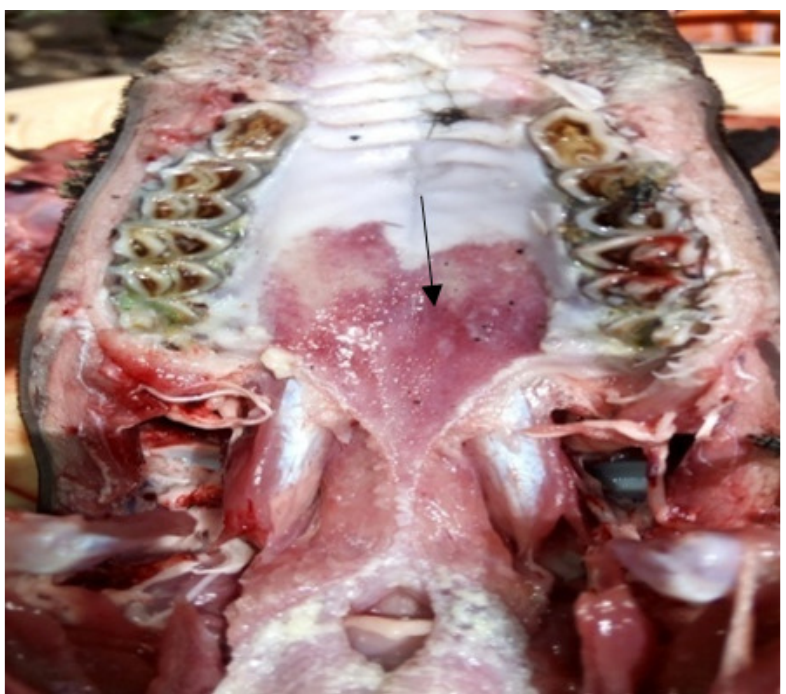

Fig. 3. Arrow pointing at the ulceration on the upper hard palate of a WAD goat suffering from PPR

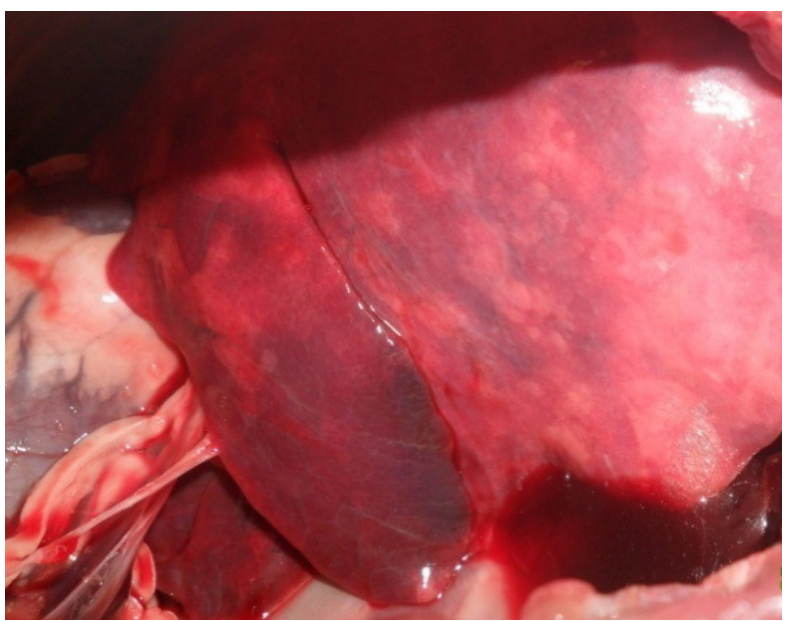

Fig. 5. Left lung showing congestion in a WAD goat suffering from PPR

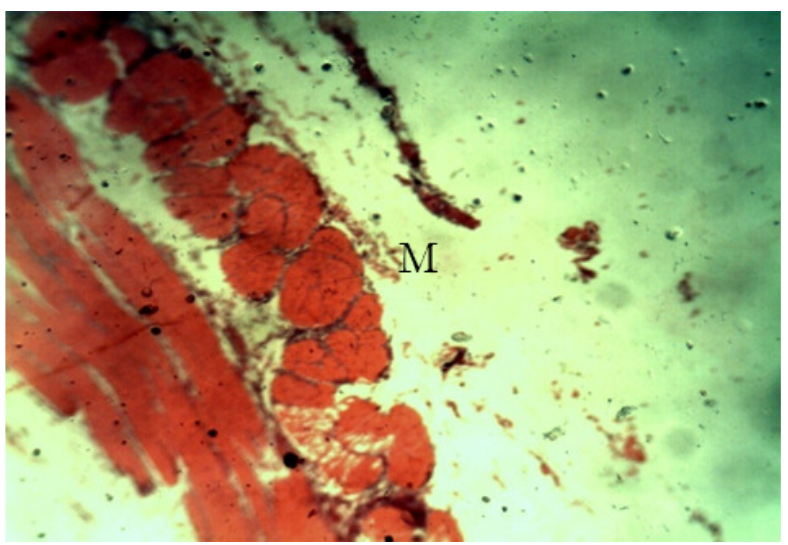

Fig. 7. Ulceration of mucosal $(\mathrm{M})$ surface of the intestines $\mathrm{X}$ $100 \mathrm{H} \& \mathrm{E}$ 
Table 1. Physiological parameters of West African dwarf goats under different treatment combinations

\begin{tabular}{|c|c|c|c|c|c|c|c|c|c|c|c|}
\hline \multirow{2}{*}{$\begin{array}{c}\begin{array}{c}\text { Group ID } \\
\text { Tag }\end{array} \\
\text { Sex/day }\end{array}$} & \multicolumn{10}{|c|}{ Temperature ${ }^{\circ} \mathrm{C}$ (respiratory rate/min) } & \multirow{2}{*}{ Mean $\pm S D$} \\
\hline & $1(\mathrm{PI})$ & $3(\mathrm{PI})$ & $5(\mathrm{PI})$ & $7(\mathrm{PI})$ & $9(\mathrm{PI})$ & $11(\mathrm{PI})$ & $13(\mathrm{PI})$ & $15(\mathrm{PI})$ & $17(\mathrm{PI})$ & $20(\mathrm{PI})$ & \\
\hline \multirow{2}{*}{$\begin{array}{l}\text { Gr. } 1 \text { IDT } 4 \\
\text { (Male) }\end{array}$} & 37.9 & 38.2 & 37.8 & 38.8 & 37.4 & 38.8 & 38.8 & 39 & 39 & 39 & $38.57 \pm 0.18$ \\
\hline & (32) & (32) & (36) & (28) & (28) & (30) & (30) & (30) & (30) & (32) & $(30.80 \pm 0.74)$ \\
\hline \multirow{2}{*}{$\begin{array}{l}\text { Gr. } 1 \text { IDT } 5 \\
\quad \text { (Male) }\end{array}$} & 38.9 & 37.7 & 37.7 & 37.7 & 36.2 & 38.4 & 38.5 & 39 & 38.5 & 39 & $38.14 \pm 0.28$ \\
\hline & (30) & (24) & (24) & (28) & (24) & (30) & (30) & (32) & (30) & (30) & $(30.00 \pm 0.99)$ \\
\hline \multirow{2}{*}{$\begin{array}{c}\text { Gr. } 1 \text { IDT } 6 \\
\text { (Female) }\end{array}$} & 39.3 & 39.3 & 38.8 & 38.6 & 37.5 & 39.5 & 39.5 & 40 & 39 & 39.5 & $39.10 \pm 0.22$ \\
\hline & (36) & (36) & (32) & (36) & (24) & (30) & (30) & (30) & (32) & (32) & $(31.80 \pm 1.17)$ \\
\hline \multirow{2}{*}{$\begin{array}{l}\text { Gr. } 1 \text { IDT } 11 \\
\text { (Female) }\end{array}$} & 38.1 & 37.8 & 38.8 & 39 & 36 & 38.3 & 38.5 & 39 & 39.5 & 40 & $38.50 \pm 0.35$ \\
\hline & (28) & (34) & (32) & (36) & (28) & (32) & (30) & (30) & (32) & (30) & $(31.20 \pm 0.80)$ \\
\hline \multirow{2}{*}{$\begin{array}{c}\text { Gr. } 2 \text { IDT } 3 \\
\text { (Male) }\end{array}$} & 37.7 & 37.7 & 38.4 & 37 & 38.1 & 38.5 & 39 & 39 & 39 & 39.5 & $38.37 \pm 0.24$ \\
\hline & (28) & (34) & (24) & (40) & (32) & (30) & (30) & (30) & (30) & (32) & $(31.00 \pm 1.31)$ \\
\hline \multirow{2}{*}{$\begin{array}{c}\text { Gr. } 2 \text { IDT } 8 \\
\text { (Female) }\end{array}$} & 38.5 & 37.5 & 38.7 & 39 & 37.2 & 28 & 38.5 & 39 & 39 & 39.5 & $38.49 \pm 0.23$ \\
\hline & (38) & (28) & (28) & (32) & (28) & (30) & (30) & (30) & (30) & (32) & $(29.40 \pm 0.60)$ \\
\hline \multirow{2}{*}{$\begin{array}{l}\text { Gr. } 2 \text { IDT } 12 \\
\quad \text { (Male) }\end{array}$} & 387 & 28 & 37 & 38 & 37 & 37.5 & 38 & 38.5 & dead & 0 & $30.27 \pm 5.05$ \\
\hline & (36) & (32) & (28) & (34) & (40) & (34) & (32) & (32) & & (0) & $(33.25 \pm 1.25)$ \\
\hline \multirow{2}{*}{$\begin{array}{l}\text { Gr. } 2 \text { IDT } 14 \\
\text { (Female) }\end{array}$} & 38.8 & 37.8 & 40 & 40.4 & 38 & 39 & 39 & 39 & 39 & 39 & $38.85 \pm 0.25$ \\
\hline & (28) & (40) & (36) & (34) & (28) & (34) & (28) & (30) & (30) & (30) & $(33.40 \pm 1.37)$ \\
\hline \multirow{2}{*}{$\begin{array}{c}\text { Gr. } 3 \text { IDT } 2 \\
\text { (Female) }\end{array}$} & 38.6 & 38.2 & 38.3 & 39.4 & 38.1 & 38 & 38.5 & 39 & 39 & 39 & $38.61 \pm 0.15$ \\
\hline & (32) & (32) & (28) & (36) & (32) & (26) & (28) & (30) & (32) & (32) & $(30.80 \pm 0.90)$ \\
\hline \multirow{2}{*}{$\begin{array}{c}\text { Gr. } 3 \text { IDT } 9 \\
\text { (Male) }\end{array}$} & 38 & 38.9 & 38.4 & 40.6 & 39 & dead & 0 & 0 & 0 & 0 & $19.46 \pm 6.50$ \\
\hline & (28) & (48) & (40) & (40) & (24) & & (0) & (0) & (0) & (0) & $(36 \pm 4.38)$ \\
\hline \multirow{2}{*}{$\begin{array}{c}\text { Gr. } 3 \text { IDT } 15 \\
\text { (Female) }\end{array}$} & 38.1 & 37.2 & 38.9 & 39.5 & 38.2 & 38 & 39 & 39 & 39.5 & 39 & $38.56 \pm 0.24$ \\
\hline & (32) & (36) & (28) & (32) & (28) & (34) & (30) & (28) & (30) & (32) & $(30.60 \pm 0.97)$ \\
\hline \multirow{2}{*}{$\begin{array}{l}\text { Gr. } 3 \text { IDT } 16 \\
\text { (Male) }\end{array}$} & 38.7 & 38.8 & 38.8 & 39.4 & 38.4 & 38.4 & 39 & 39.5 & 39 & 39.5 & $38.95 \pm 0.13$ \\
\hline & (32) & (36) & (32) & (40) & (28) & (30) & (30) & (28) & (30) & (30) & $(31.60 \pm 1.19)$ \\
\hline \multirow{2}{*}{$\begin{array}{l}\text { Gr. } 4 \text { IDT } 1 \\
\text { (Male) }\end{array}$} & 37.1 & 38.4 & 38.5 & 38.8 & 39.7 & 37.8 & 38 & 38 & 39 & 39.5 & $38.48 \pm 0.25$ \\
\hline & (28) & (36) & (28) & (32) & (37) & (40) & (38) & (36) & (36) & (34) & $(34.50 \pm 1.28)$ \\
\hline \multirow{2}{*}{$\begin{array}{c}\text { Gr. } 4 \text { IDT } 7 \\
\text { (Female) }\end{array}$} & 37.9 & 37.6 & 37.8 & dead & 0 & 0 & 0 & 0 & 0 & 0 & $11.33 \pm 5.77$ \\
\hline & (36) & (36) & (38) & & (0) & (0) & (0) & (0) & (0) & (0) & $(35.33 \pm 0.67)$ \\
\hline \multirow{2}{*}{$\begin{array}{c}\text { Gr. } 4 \text { IDT } 8 \\
\text { (Female) }\end{array}$} & 38.5 & 37.5 & 38.7 & 39 & 37.2 & 28 & 38.5 & 39 & 39 & 39.5 & $38.49 \pm 0.23$ \\
\hline & (38) & (28) & (28) & (32) & (28) & (30) & (30) & (30) & (30) & (32) & $(29.40 \pm 0.60)$ \\
\hline \multirow{2}{*}{$\begin{array}{l}\text { Gr. } 4 \text { IDT } 13 \\
\text { (Male) }\end{array}$} & 38.1 & 37.3 & 39.5 & 37.6 & 36.2 & 37 & 38 & 39 & 39 & 39 & $38.07 \pm 0.34$ \\
\hline & (32) & (28) & (40.4) & (28) & (36) & (32) & (32) & (30) & (30) & (30) & $(31.80 \pm 1.17)$ \\
\hline \multirow{3}{*}{$\begin{array}{c}\text { Mean } \pm \mathrm{SD}{ }^{\circ} \mathrm{C} \\
(\min )\end{array}$} & $38.33 \pm 0.14$ & $38.05 \pm 0.15$ & $38.31 \pm 0.15$ & $38.86 \pm 0.26$ & $37.59 \pm 0.27$ & $38.13 \pm 0.19$ & $38.59 \pm 0.13$ & $39.00 \pm 0.12$ & $39.04 \pm 0.07$ & $39.31 \pm 0.09$ & \\
\hline & $(31.13 \pm$ & $(34.50 \pm$ & $(31.88 \pm$ & $(33.33 \pm$ & $(31 \pm$ & (31.14 & $(30.57 \pm$ & $(30.43 \pm$ & $(31.38 \pm$ & $(31.38 \pm$ & \\
\hline & 0.88) & $1.40)$ & 1.24) & $1.15)$ & $1.22)$ & $0.83)$ & $0.71)$ & $0.52)$ & $0.47)$ & $0.25)$ & \\
\hline
\end{tabular}

PI-Post Infection; IDT-Identity Tag; SD- Standard Deviation

Table 2. Morbidity and mortality pattern in different treatment combinations

\begin{tabular}{|c|c|c|c|c|}
\hline Groups & Neck tag no & Sex & \%orbidity & \%Mortality \\
\hline \multirow{4}{*}{ Group 1} & 4 & Male & \multirow{4}{*}{$100 \%$} & \multirow{4}{*}{$0 \%$} \\
\hline & 5 & Male & & \\
\hline & 6 & Female & & \\
\hline & 11 & Female & & \\
\hline \multirow{4}{*}{ Group 2} & 3 & Male & \multirow{4}{*}{$100 \%$} & \multirow{4}{*}{$25 \%$} \\
\hline & 8 & Female & & \\
\hline & (12) & Male & & \\
\hline & 14 & Female & & \\
\hline \multirow{4}{*}{ Group 3} & (2) & Female & \multirow{4}{*}{$100 \%$} & \multirow{4}{*}{$50 \%$} \\
\hline & (9) & Male & & \\
\hline & 15 & Female & & \\
\hline & 16 & Male & & \\
\hline \multirow{4}{*}{ Group 4} & 1 & Male & \multirow{4}{*}{$100 \%$} & \multirow{4}{*}{$75 \%$} \\
\hline & (7) & Female & & \\
\hline & (8) & Female & & \\
\hline & (13) & Male & & \\
\hline
\end{tabular}


384

\section{Discussion}

The clinical manifestations of PPR observed in this study agree with the findings in previous studies by Jalees $e t$ al. (2013), Pope et al. (2013), Balamurugan et al. (2014), Das et al. (2015).

The physiological parameters namely temperature, respiratory rates and pulse rates were higher in untreated infected WAD goats (group 4) when compared with those in group 1, 2 and 3 which were treated, this agrees with the findings of previous researchers like Tariq and Shahzad (2013); Mahmud and Galbat (2017) and Meher et al. (2017).

The slight increase in the respiratory rate could be due to pulmonary involvement, which is a constant feature of peste des petits ruminants, this is due to the fact that PPR virus induced immune-suppression predisposes to secondary bacterial infections, where pneumonia is the most frequently observed bacterial complication in peste des petits ruminants virus (PPRV) infected animals (Chauhan et al., 2009; Abubakar et al., 2015b).

Same for the mortality in the untreated group, it was higher than what was recorded for the treated groups. This finding agrees with findings of Diallo et al. (2006), Abubakar et al. (2011) and Mahajan et al. (2012).

The morbidity pattern in all the treatment groups was $100 \%$, the percentage mortality was $0 \%$ in group 1 . This experiment showed that the incorporation of the antiviral agent, amantadine HCL reduced the mortality to zero. Amantadine HCL also known as Symmetrel, is a recognized antiviral agent against paramyxoviruses. It acts by interfering with viral penetration, uncoating and assembly (Saliki, 1998). It has been effectively used in treating human influenza (Allen et al., 2006).

Narayanan et al. (2008), treated clinical cases of PPR were treated with broad-spectrum antibiotics. The findings of this present study supports the argument that incorporation of oxytetracycline into the treatment regime of PPR can be effective in combating secondary bacterial infection in PPR infection (Ugochukwu et al., 2017a).

Levamisole incorporated into the treatment regimen in WAD goats in group 1, 2 and 3 and as evidently shown in the findings from animals in group 3, helped reduce mortality and morbidity because of its role as an anthelminthic and immune-potentiator and should be considered in the treatment regimen in PPR infection.

\section{Conclusions}

In conclusion, in areas that cannot be effectively covered by vaccination especially, where there is an outbreak of the deadly disease, incorporation of specific antiviral agents like amantadine hydrochloride in the treatment regimen with oxytetracycline and levamisole as observed in chemotherapeutic group 1, particularly during the early stages of the infection when they provide a good curative option that can reduce morbidity and mortality of the disease to the barest minimum. Further work is envisaged to assess fully the possible immune-potentiating ability of levamisole in the management of PPR. Based on the results of this experiment, amantadine hydrochloride, an antiviral agent against paramyxoviruses is recommended in combination with long acting oxytetracycline and levamisole in the chemotherapy of peste des petits ruminants not only to reduce the morbidity but also the mortality in natural infections of PPR.

\section{Acknowledgements}

The authors are grateful to staff of the Viral Research Division of the Nigeria Veterinary Research Institute, Vom, Plateau State and of the Department of Veterinary Medicine, University of Nigeria, Nsukka, for their expert technical assistance.

\section{Ethical Considerations}

The ethical conditions governing the use and conduct of experiments with live animals were strictly observed by Ward and Elsea (1997) and the experimental protocol was approved by the Senate committee on Medical and Research ethics, University of Nigeria, Nsukka.

\section{Authors' Contributions}

E.I. Ugochukwu conceived the idea, E.I. Ugochukwu, I.C Ugochukwu and C.F. Ikem carried out the research, and I.C. Ugochukwu, J.N. Omeke and I.C. Aneke wrote the manuscript while N.A. Sani, N.T. Emejuo and I.S. Idoko did the statistical analysis and also made immense intellectual contribution to this research. All authors read and approved the manuscript for submission.

\section{Conflict of Interest}

The authors declare that there are no conflicts of interest related to this article.

\section{References}

Abu Elzein EM, Hassanien MM, Al-Afaleq AI, AbdElhadi MA, Housawi FM (1990). Isolation of peste des petits ruminants from goats in Saudi Arabia. Veterinary Record 127:309-310.

Abubakar MS, Ashiq Z, Hussain M, Hussain SH, Saleha MJ, Arshed, Zahoor $\mathrm{AB}$ (2011). Comparison of antigen detection methods of peste des petits ruminants virus in clinical samples of small ruminants. Bulgaria Journal of Veterinary Medicine 14:103-108.

Abubakar M, Irfan M (2014). An overview of treatment options to combat peste des petits ruminants (PPR). Research Journal Veterinary Practise 2(1):47.

Abubakar M, Manzoor S, Ali Q (2015b). Evaluating the role of vaccine to combat peste des petits ruminants outbreaks in endemic disease situation. Journal of Animal Science and Technology 57(1):2.

Abubakar M, Irfan, M, Manzoor S (2015a). Peste des petits ruminants in Pakistan; past, present and future perspectives. Journal of Animal Science and Technology 57(1):32.

Ademosun AA (1994). Constraints and prospects for small ruminants' research and development in Africa. In: Lebbie SHB, Rey B, Irungu EK 
(Eds). Small ruminants' research and development in Africa. Proceedings of the 2nd Biennial Conference of the Africa Small Ruminants Research Network, Arusha, 1992. International Livestock Centre for Africa, Technical Centre for Agricultural and Rural Cooperation, Addis Ababa, pp 1-6.

Adu FD, Joannis T (1985). Goat hyper-immune serum for the diagnosis of PPR Veterinary Record 117(18):472-472.

Allen UD, Aoki FY, Stiver HG (2006). The use of antiviral drugs for influenza: recommended guidelines for practitioners. Canadian Journal ofInfectious Diseases and Medical Microbiology 17(5):273-284.

Anene BM, Ugochukwu EI, Omamegbe JO (1987). An appraisal of three treatment regimens for pneumoenteritis complex (PPR) in goats. Bulletin of Animal Health and Production in Africa 35:1-3.

Adombi CM, Lelenta M, Lamien CE, Shamaki D, Koffi YM, Traoré A, ... Diallo A (2011). CV1 cell line expressing the sheep-goat SLAM protein: a highly sensitive celline for the isolation of peste des petits ruminants virus from pathological specimens. Journal of Virological Methods 173:306-313.

Balamurugan V, Hemadri D, Gajendragad MR, Singh RK, Rahman H (2014). Diagnosis and control of peste des petits ruminants: a comprehensive review. Virus Disease 25(1):39-56.

Baron MD, Parida S, Oura CAL (2011). Peste des petits ruminants: a suitable candidate for eradication? Veterinary Records 169:16-21.

Brown CC, Mariner J, Olander HJ (1991). An immunohistochemical study of the pneumonia caused by peste des petits ruminants virus. Veterinary Pathology 28:166-170.

Chauhan HC, Chandel BS, Kher HN, Dadawala AI, Agrawal SM (2009). Peste des petits ruminants virus infection in animals. Veterinary World 2(4):150-155.

Chukwu CC (1987). Cell-mediated immune responses of cattle following Brucella abortus strain 19 vaccination and simultaneous administration oflevamisole. Microbios Letters 34:2-17.

Das S, Nath R, Balamurugan V, Choudhury R, Devi M (2015). Haematobiochemical analysis of goats naturally infected with peste des petits ruminants. International Journal ofEmerging Trends in Science and Technology 2(9):19-24.

Diallo A (2006). Control of peste des petits ruminants and poverty alleviation? Journal of Veterinary Medicine 53:11-13.

Drury R, Wallington E. (1980) Carleton's histological techniques. $5^{\text {th }} \mathrm{ed}$. Oxford University Press.

Ezeibe MCO, Wosu LO, Erumaka IG (2003). Standardization of the haemagglutination test for peste des petits ruminants (PPR). Small Ruminant Research 51(3):269-272.

FAO (2011). OIE and FAO, Food and Agriculture Organization. The global rinderpest eradication programme. Progress report on rinderpest eradication: success stories and actions leading to the June 2011 Global Declaration. Retrieved 2019 February 11 from http://www.fao.org/ag/againfo/resources/documents/AH/GREP_fly er.pdf.

Hardman JG, Limbird LE (2001). The pharmacological basis of therapeutics. McGraw-Hill(10thed.), pp 1477.

Islam MS, Khan MSI, Kader HA, Begum MR, Asgar MA (2012). Prevalence of PPR of goat and their response to antibiotic treatment at
Mirzaganj Upazila of Patuakhali District. Journal of Environmental Science and Natural Resources 5(2):181-184.

Jalees MM, Hussain I, Arshad M, Muhammad G, Khan QM, Mahmood MS (2013). Occurrence of peste des petitis ruminants in five districts of Punjab, Pakistan. Pakistan VeterinaryJournal 33(2):165-169.

Khaskheli AA, Ibrahim Khaskheli MI, Khaskheli A, Khaskheli G, Abro R, Barha GS (2017). Clinical prevalence of peste des petits ruminants (PPR) disease in small ruminants at the urban areas of hyderabad, Sindh. Journal of Basic and Applied Sciences 13:281-286.

Libeau G, Diallo A, Parida S ( 2014). Evolutionary genetics underlying the spread of peste des petits ruminants virus. Animal Frontiers 4:1420.

Lombard M, Pastoret PP, Moulin AM (2007). A brief history of vaccines and vaccination. Revue scientifique et technique. International Office of Epizootics 26:29-48.

Mahajan S, Agrawal R, Kumar M, Mohan A, Pande N (2012). Risk of seroconversion to peste des petits ruminants (PPR) and its association with species, sex, age and migration, Small Ruminant Research 104:195200.

Mahmoud MA, Galbat, SA (2017).Outbreak of foot and mouth disease and peste des petits ruminants in sheep flock imported for immediate slaughter in Riyadh. Veterinary World 10(2):238-243.

Manoharan SR, Jayakumar R, Govindarajan Koteeswaran A (2005). Haem agglutination as a confirmatory test for peste des petitsruminants diagnosis. Small Ruminant Research 59(1):75-78.

Mbyuzia AO, Kombab EVG, Kimerab, SI, Kambarage DM (2014). Seroprevalence and associated risk factors of peste des petit ruminants and contagious caprine pleuro-pneumonia in goats and sheep in the Southern Zone of Tanzania. Preventive Veterinary Medicine 116:138144 .

Meeusen ENT, Walker J, Peters A, Pastoret PP, Jungersen G (2007). Current status of veterinary vaccines. Clinical Microbiology Review 20:489-510.

Meher M, Afrin M, Hassan Z, Alam J (2017). Epidemiological investigation of peste des petits ruminant's virus infection in goat with therapeutic management at Beraupazila of Pabna in Bangladesh.Progressive Agriculture 28(2):114119.

Narayanan R, Gopu P, Baegan S (2008) Clinical management in an outbreak of peste des petits ruminants in Barbari goats. Veterinary World 1(3):81-82.

Nduaka O, Ihemelandu EC (1973). Observations on pneumoenteritis complex in dwarf goats in eastern region of Nigerian-preliminary report. Bulletin of Epizootic Disease in Africa 21:89-98.

Perry BD, Randolph TF, McDermott JJ, Sones KR, Thornton PK (2002). Investing in animal health research to alleviate poverty. International Livestock Research Institute, Nairobi, Kenya.

Pope RA, Parida S, Bailey D, Brownlie J, Barrett T, Banyard AC (2013). Early events following experimental infection with peste-des-petits ruminants virus suggest immune cell targeting. PLoSOne 8(2):e55830.

OIE and FAO (2015).Global strategy for control and eradication of PPRFAO and OIE International conference for the control and eradication of Peste Des Petits Ruminants (PPR), Abidjan, Cote D”Ivoire, 31 March-2 April 2015, pp 1- 83. http://www.fao.org/3/ai4460e.pdfaccessed on 05/11/2018 
386

Riedel S (2005). Edward Jenner and the history of smallpox and vaccination. In: Baylor University Medical Center Proceedings 18(1):21-25.

Roeder PL, Obi TU (1999). Food and Agriculture Organization [FAO] of the United Nations. Recognizing peste des petits ruminants. Retrieved 2018 July 25 from http://www.fao.org/3/x1703e/x1703e00.htm.

SalikiJT (1998). Peste des petits ruminants. In: US animal health association, committee on foreign animal disease. Foreign animal diseases: the gray book. Ed 6. Part IV. VA: US Animal Health Association. Richmond pp344352.

Singh RP, Sreenivasa BP, Dhar LP, Shah C, Bandyopadhyay SK (2004). Development of a monoclonal antibody based competitive-ELISA for detection and titration of antibodies to peste des petits ruminants (PPR) virus. Veterinary Microbiology 98(1):3-15.

Taki HN, Schwartz SA (1994). Levamisole as an immunopotentiator for T cell deficiency. Immunopharmacology and Immunotoxicology 16(2):129-137.

Tariq A, Shahzad A (2013). Diagnosis of peste des petits ruminant in 2 year old buck on the basis of clinical signs and haematology. International Journal of Molecular Veterinary Research 3(9):51-54.

Taylor WP (1979). Serological studies with the virus of peste des petits ruminants in Nigeria. Research in Veterinary Science 26:236-242.

Ugochukwu EI (1983). Haematological observation of goats suffering from natural infection of pneumo-enteritis complex. Bulletin of Animal Health and Production in Africa31:337-341.

Ugochukwu ICI, Ugochukwu EI, Chukwu CC (2017a). Therapeutic response of West African dwarf goats infected with peste des petits ruminants whose oral lesions were treated with oxytetracycline long acting and gentian violet topical spray. Asian Pacific Journal of Tropical
Diseases 7(12):771-774.

Ugochukwu IC, Shoyinka SVO, Chineme CN, Chah KF (2017b). Prevalence, histopathological finding and aerobic bacteria flora associated with pneumopathies in goats slaughtered in the Nsukka abattoir. Sokoto Journal of Veterinary Science 15(4):46-52.

Ugochukwu ICI, Ezeasor CK, Agina OA, Anyogu DC, Chukwudi IC, Idoko SI,Ugochukwu EI (2019). Peste des petits ruminants: aetiology, pathology, immunology, disease status in Africa, diagnosis, control, prevention and treatment: a review. Notulae Scientia Biologicae 11(1):12-20.

Undiandeye JU, Oderinde BS, El-Yuguda A, Baba SS (2014). Immunostimulatory effect of levamisole on the immune response of goats to peste des petits ruminants (PPR) vaccination. World Journal of Vaccines 4(2): 45852.

Ward JW, Elsea JR (1997). Animal case and use in drug fate and metabolism, methods and techniques. Marcel Deker, Vol 2. New York pp372-390.

Wosu LO (1989). Management of clinical cases of peste des petits ruminants (PPR) disease in goats. Beitrage zur Tropischen Landwirtschaft und Veterinarmedizin 27(3):357-361. 